\section{PRODUCTIVITY MANAGEMENT}

\section{JOSEPH PROKOPENKO}

Genève, Bureau International du Travail, 1987.

\section{Por Claude Machline}

Professor Titular do Departamento de Administração da Produção e de Operações Industriais da EAESP/FGV.

Joseph Prokopenko é consultor senior do Serviço de Aperfeiçoamento de Dirigentes da OIT (Organização Internacional do Trabalho).

Neste livro, de 317 páginas, ele aborda, de maneira abrangente, o tema da Produtividade.

Um resumo do índice mostra a envergadura do tópico:

- Cap. 1. Conceito e definição de produtividade

- Cap. 2. Fatores de melhoria da produtividade

- Cap. 3. Análise (medição) da produtividade

- Cap. 4. Como obter a eficácia

- Cap. 5. Técnicas de melhoria da produtividade

- Cap. 6. Melhor emprego dos recursos materiais

- Cap. 7. Gestão eficaz dos recursos humanos

- Cap. 8. Promoção da produtividade a nível nacional

Havia cem anos, o assunto esgotava-se com a Engenharia Industrial. Hoje, a produtividade tem mil faces. Enquanto a maioria dos autores, atualmente, só nos mostra o rosto oriental da produtividade, Prokopenko, de forma rara, explora os enfoques tradicionais e modernos, os conceitos baseados nas máquinas e os que se fundamentam no homem, os princípios nascidos na Europa e nos Estados Unidos e os métodos originados no Japão. Exemplos são extraídos de numerosos países, do Canadá às Filipinas, da Índia à Nigéria, refletindo a procura incessante da eficiência através do mundo, condição indispensável para a sobrevivência do homem e a competitividade das nações.

Houve épocas em que o interesse pelo assunto esteve extremado, notadamente após a Segunda Guerra Mundial, quando urgia reconstruir as economias dos países destruídos; na década dos sessenta, a preocupação esteve centrada na produtividade das pequenas e médias empresas $\mathrm{e}$ dos países em desenvolvimento; e, nestas duas últimas décadas, houve fascínio pela tecnologia $\mathrm{e}$ pela administração japonesas.

Apesar do muito que se tem escrito acerca de produtividade, o assunto, lembra o autor, é árido. Assusta e afasta. O mero termo faz tremer o trabalhador, que o associa ao velho trabalho escravo ou à perda do emprego, à monotonia e à exaustão da linha de montagem ou à substituição do homem pela máquina.

Ao contrário, Produtividade significa trabalho mais inteligente e mais humano, com a máquina melhor utilizada ao serviço do homem, com o esforço melhor dirigido, resultando em redução de custos e aperfeiçoamento da qualidade.

$O$ capítulo 3 , dedicado à medição da prođutividade, é recheado de fórmulas, que, infelizmente, não são acompanhadas de exemplos numéricos que facilitariam sua compreensão, permanecendo em um nível excessivamente abstrato.

Em compensação, os três capitulos seguintes oferecem bons exemplos, notadamente os casos da Texas Instruments, da Sanyo Electronics, da Toyota, do Hospital Geral de Norwalk, da Ewekoro Cement Works da Nigéria, de uma fábrica de conexões da Índia e da Hughes Aircraft Company.

Entre os métodos melhor descritos no livro, destacam-se, no que tange ao diagnóstico:

- as comparações entre empresas idênticas.

- a análise $A B C$ (Pareto)

- o diagrama de Ishikawa

- as análises econômicas e de custos

Dentro das técnicas de melhoria de produtividade, sobressaem:

- o estudo do trabalho

- a análise de valor

- os métodos kanban e just-in-time de redução de estoques

- os círculos de qualidade 
- o controle total da qualidade

- as caixas de sugestões

- a conservação da energia

- a manutenção preventiva

- a participação nos lucros

O leitor encontrará informações valiosas acerca de organismos internacionais ou regionais dedicados ao fomento da produtividade no mundo. Dezenas deles são citados, com ênfase na própria Organização Internacional do Trabalho(OIT), que atua no quadro da ONU (Organização das Nações Unidas).

O Brasil e, de um modo geral, a América Latina, nunca são mencionados neste livro, exceto pela anotação isolada de que existe uma entidade denominada MECOPOR, fundada em 1984; é uma organização dedicada à produtividade na América Latina e no Caribe, à semelhança da Associação Européia dos Centros Nacionais de Produtividade (AECNP) e da Organização Asiática de Produtividade (OAP).

As organizações e os esforços de alguns países nesse âmbito, notadamente o Canadá, a Índia, o Japão, a República Federal da Alemanha, a Noruega, Singapura e as Filipinas, são descritos.

A edição espanhola do livro traz o subtítulo: "Manual Prático" (de Produtividade). É uma inverdade. Mais correto seria o subtítulo: "Manual Introdutório", para esse livro genérico, que examina, com méritos (considerando a amplidão do tema), seus diversos ângulos, econômico, técnico, administrativo, social, histórico, institucional, mas nunca entra em detalhes e jamais esmiuça com profundidade os assuntos tratados. O objetivo principal do autor é reabilitar o termo produtividade, desfazendo mitos; não é habilitar técnicos na área.

Em resumo, a obra aqui resenhada constitui apreciável contribuição para os leitores que desejam ter uma visão geral do assunto, de tão grande relevância para países que, como o Brasil, falam tanto em crescimento e tão pouco em aumentar a produtividade.

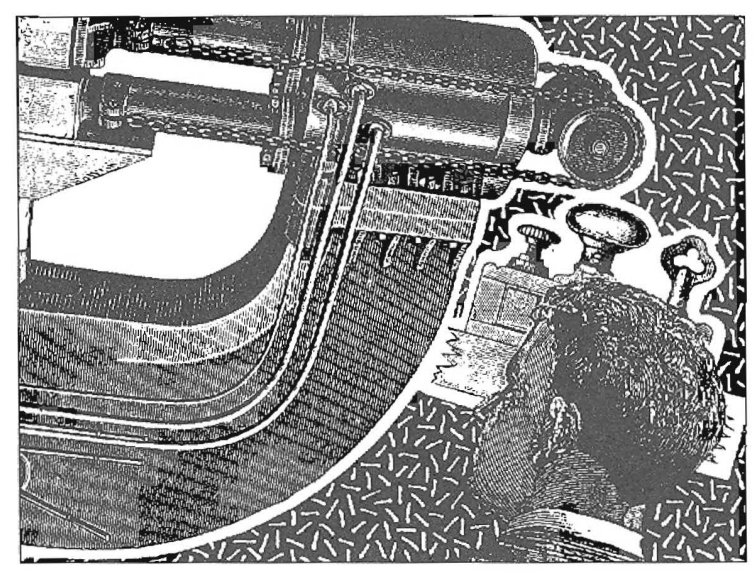

\section{LOGISTICA: SUPRIMENTOS, ARMAZENAGEM, DISTRIBUIÇÃO}

\author{
REINALDO APARECIDO MOURA \\ São Paulo, Instituto de Movimentaçāo e \\ Armazenagem de Materiais (IMAM), 1989, II + \\ 349 páginas.
}

\section{Por Kurt Ernst Weil}

Chefe do Departamento de Administração da

Produção e de Operações Industriais da

EAESP/FGV.

Resenhar um livro que, na realidade, é um resumo dos grandes conhecimentos do autor é difícil. Seria mais fácil dizer que o título devia ser "Resumos de Logísticas - para o administrador e usuário", pois o autor, apesar de não fazer nenhuma referência a isso no prefácio, deixa claro que não procura fazer um tratado de exatidão científico-matemática, com deduções ou com definições perfeitas.

Exemplo, na seção "Custos" - a definição é "mão-de-obra, dinheiro e material são os elementos do comércio que têm influência direta nos lucros e custos". Definição para poder trabalhar, mas não completa, pois deixa fora o custo do ponto e das instalações (pág. 23). Não tem importância para o uso a que o livro se destina - conseguir em poucas páginas dar uma visão da logística, fazendo uma recapitulação geral de critérios econômicos, administrativos e de engenharia. Das 34 páginas do capítulo 2 , são atribuídas umas 20 ao estado econômico da armazenagem e distribuição, o que evidencia o interesse prático acima do acadêmico. O lote econômico, página 67 , e o sistema $A B C$, página 61 , demonstram e evidenciam o sentido eminentemente prático do livro, pois, mais uma vez, não há demonstraçôes - Q.E.D.

Assim, o volume "Logística" é ideal para cursos de atualização e introdução. Tudo que for importante é tratado numa linguagem clara e simples e com excelentes ilustrações. Não há exatidão absoluta, mas isso não deve ser criticado, pois não é a finalidade da obra. Outro indício está na bibliografia resumida a poucos volumes, sem citar certos autores que hoje são considerados os papas da disciplina. Os capítulos 10 e 11, que falam do uso do computador na "Armazenagem" e no Layout, têm certa dose de matemática de nível superior, cujo entendimento não é, entretanto, essencial para seguir ao desenrolar dos capítulos. Não é necessário, nesse ponto, discutir a separação de layout horizontal (capítulo 11) e vertical (capítulo 12) e volumétrico. Para mim, seria uma só área integrada, já que os corredores e o tipo de empilhadeira são uma só equação, e a altura da elevação da empilhadeira é um problema de imobilização (?) em 